\title{
Infecciones respiratorias virales en episodios de fiebre en niños con trasplante de precursores hematopoyéticos
}

\author{
Respiratory viral infections during episodes of fever in children undergoing hematopoietic \\ stem cell transplantation
}

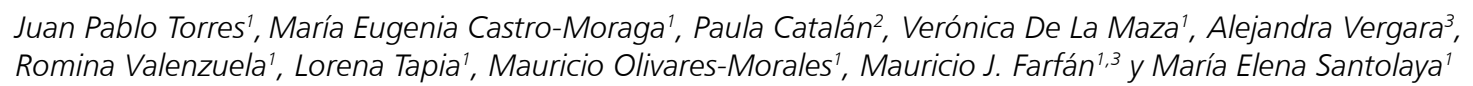

'Departamento de Pediatría y Cirugía Infantil Oriente, Unidad de Infectología, Hospital Luis Calvo Mackenna, Facultad de Medicina, Universidad de Chile. Santiago, Chile. ${ }^{2}$ Hospital Luis Calvo Mackenna, Unidad de Trasplante de Medula Ósea. Santiago, Chile.

${ }^{3}$ Hospital Luis Calvo Mackenna, Laboratorio Biología Molecular. Santiago, Chile.

Los autores declaran no tener conflicto de interés.

Proyecto financiado por el Proyecto FONDECYT Regular 1171795

Juan Pablo Torres y María Eugenia Castro-Moraga son ambos primeros co-autores del presente estudio.

Recibido: 10 de marzo de 2020 / Aceptado: 5 de junio de 2020

\section{Resumen}

Introducción: Los niños que reciben trasplante de precursores hematopoyéticos (TPH) pueden presentar infecciones respiratorias virales (IRV) durante episodios febriles. Los datos sobre su evolución clínica son escasos, así como la comparación de ellos con infecciones bacterianas (IB). Objetivo: Caracterizar la evolución clínica de pacientes con IRV, en comparación con IB en niños con TPH, cursando un episodio febril. Método: Estudio prospectivo en pacientes $\leq 18$ años con cáncer y TPH ingresados por fiebre en el Hospital Luis Calvo Mackenna (20162019). Se realizó evaluación clínica y de laboratorio: hemocultivos, RPC para patógenos respiratorios (Filmarray ${ }^{\circledR}$ ), cuantificación viral y medición de citoquinas en muestra nasal (Luminex ${ }^{\circledR}, 38$ citoquinas). Se compararon los grupos IRV, IB y los de etiología no precisada (ENP) en relación con: infección respiratoria aguda (IRA), citoquinas nasales, ingreso a UCI, necesidad de ventilación mecánica, mortalidad y suspensión de antimicrobianos. Resultados: De 56 episodios febriles, 35 fueron IRV, 12 IB y 9 de ENP. Mediana de edad fue 8,5 años, $62 \%$ masculino. Un $94 \%$ de los casos IRV presentó IRA sintomática, versus 33\% en los grupos IB y ENP ( $p<0,001)$, con IRA baja en $69 \%$ de las IRV $(p<0,001)$. Rinovirus $(54 \%)$ y coronavirus $(15 \%)$ fueron las etiologías más frecuentemente detectadas. No hubo diferencias en citoquinas nasales entre los grupos IRV e IB. Ingreso a UCI: $11 \%$ del grupo IRV, $17 \%$ de IB y $11 \%$ de ENP ( $p=0,88)$. Requirieron ventilación mecánica sólo 2 pacientes $(\mathrm{p}=0,37)$ sin fallecimiento. Tras la detección viral respiratoria por RPC, se suspendió antimicrobianos en $26 \%$ de los casos con IRV $(\mathrm{p}=0,04)$. Conclusión: Las IRV son frecuentes en niños con TPH y episodios febriles. La detección viral podría optimizar y racionalizar el uso de antimicrobianos en esta población.

Palabras clave: niños; cáncer; trasplante de precursores hematopoyéticos; infección respiratoria viral; reacción de polimerasa en cadena multiplex.

\section{Abstract}

Background: Children undergoing hematopoietic stem cell transplant (HSCT) can develop respiratory viral infections (RVI) during fever episodes. There are few data about clinical outcomes in RVI and compared to bacterial infections (BI) in this population. Aim: To determine clinical outcome of RVI, compared to BI in children with HSCT. Methods: Prospective study, patients $\leq 18$ years with cancer and HSCT admitted with fever at a National Bone Marrow Transplant Center (Hospital Calvo Mackenna), Chile, (April-2016 to May-2019). Clinical assessment, laboratory tests, blood cultures, nasopharyngeal sample for multiplex-PCR (Filmarray ${ }^{\circledR}$ ), viral loads by PCR and cytokine panel (Luminex ${ }^{\circledR}, 38$ cytokines) were performed. The following outcomes were evaluated: upper/lower respiratory tract disease (RTD), admission to ICU, mechanical ventilation, mortality and antimicrobial withdrawal. Results: Of 56 febrile episodes, 35 (63\%) were RVI, 12 $(21 \%)$ BI and $9(16 \%)$ with unknown etiology (UE). Median of age was 8.5 years, $62 \%$ male gender. Rhinovirus $(54 \%)$ and coronavirus $(15 \%)$ were the more frequent detected viruses. No significant differences in cytokine levels were observed between RVI and BI. 94\% of RVI patients had symptomatic RTD, versus $33 \%$ in BI and 33\% in UE group $(\mathrm{p}<0.001)$, with lower-RTD in $69 \%$ of RVI group $(\mathrm{p}<0,001)$. Admission to ICU was $11 \%$ in RVI, $17 \%$ in BI and $11 \%$ in UE group $(\mathrm{p}=0.88)$; only 2 patients required mechanical ventilation $(\mathrm{p}=0.37)$ and no mortality was reported. After an RVI was detected by PCR, antimicrobials were withdrawal in $26 \%$ of patients with RVI (p: 0.04 ). Conclusion: RVI are frequent etiologic agents in febrile episodes of patients with HSCT. Viral detection might help to rationalize the use of antimicrobials in this population.

Keywords: children; cancer; hematopoietic stem cell transplant; respiratory viral infection; multiplex polymerase chain reaction.

Correspondencia a:

Juan Pablo Torres Torretti

jptorres@uchile.cl 


\section{Introducción}

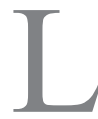

as infecciones respiratorias virales (IRV) son causa frecuente de fiebre en la edad pediátrica ${ }^{1}$.

En pacientes inmunocomprometidos, especialmente aquellos receptores de trasplante de precursores hematopoyéticos (TPH), los episodios febriles pueden tener etiologías similares al inmunocompetente. Si bien en el paciente que recibe un TPH las infecciones bacterianas (IB) y fúngicas son las más estudiadas y las que principalmente se han asociado a morbimortalidad, las IRV también pueden ser frecuentes ${ }^{2}$. Estas últimas se han asociado a una morbilidad significativa, ya sea por la progresión a infección respiratoria aguda (IRA) baja ${ }^{3}$, como por constituir una causa de hospitalización. Se ha descrito que $17 \%$ de los receptores de TPH tuvieron al menos una hospitalización debido a una IRV dentro del primer año de su trasplante ${ }^{4}$. Además, otros reportes han mostrado cifras de mortalidad asociada en un rango variable entre $1,7^{5}$ y $10 \%{ }^{6}$ en niños con TPH.

En relación al diagnóstico etiológico, la detección de antígeno por inmunofluorescencia directa es un método rápido, económico y habitualmente disponible para diagnosticar IRV, pero posee una sensibilidad variable. Esto ha determinado que la reacción en cadena de la polimerasa (RPC) en tiempo real sea el método actual de elección para la detección de IRV, debido a su alta sensibilidad, especificidad y rapidez ${ }^{7}$. Esto último es especialmente importante en pacientes inmunocomprometidos, para quienes la celeridad del diagnóstico y el inicio de tratamiento puede ser determinante en la evolución clínica y en la aparición de complicaciones potencialmente graves. Los paneles de RPC multiplex pueden analizar de manera eficiente múltiples virus al mismo tiempo ${ }^{8,9}$ y pueden detectar hasta $94 \%$ de los patógenos virales con un tiempo de respuesta promedio de $75 \mathrm{~min}^{3}$.

Existen pocos datos en niños que reciben TPH sobre la evolución clínica de las IRV y de su comparación con episodios causados por infecciones bacterianas. Al revisar el impacto de las IRV en niños receptores de TPH (Anexo 1), se destaca la frecuente incidencia de IRV desde $6 \%{ }^{6}$ hasta $40 \%$ acumulado a tres años post trasplante $^{10}$ y la mortalidad variable antes mencionada, llegando hasta $10 \%$ dentro de los primeros 100 días post trasplante ${ }^{6}$. Los virus más frecuentemente detectados en algunos estudios fueron rinovirus, virus parainfluenza y virus respiratorio sincicial ${ }^{4,5}$, mientras que en otras series se mencionan a coxsackie/echovirus y coronavirus como causa frecuente ${ }^{11}$. La detección de co-infección viral se observó hasta en $45 \%$ de los $\operatorname{casos}^{6}$. Algunos estudios se refieren también a la relación entre detección viral pre-trasplante, tanto en pacientes sintomáticos como asintomáticos, e infección post trasplante.
Además, se desconoce el impacto de la detección de la IRV respecto a la consecutiva suspensión o no de antimicrobianos.

Por otra parte, la respuesta inmune del hospedero frente a diversos patógenos ha sido estudiada mediante la medición de citoquinas, moléculas efectoras esenciales para la respuesta inmune innata y adaptativa ${ }^{12,13}$. Si bien, en el paciente inmunocompetente se han caracterizado perfiles para diversos patógenos ${ }^{14,15}$, hay poca evidencia sobre la respuesta local y producción de citoquinas en receptores de TPH ante una IRV.

El objetivo de este estudio fue caracterizar la evolución clínica de pacientes con IRV, en comparación con aquellos cursando una IB, así como determinar la carga viral, la respuesta local de citoquinas y la suspensión de antimicrobianos, en niños con TPH cursando un episodio febril.

\section{Pacientes y Métodos}

\section{Población en estudio y diseño}

Estudio prospectivo en pacientes bajo 18 años de edad, con cáncer, que hubieran recibido $\mathrm{TPH}$, ingresados por fiebre a la Unidad de Trasplante de Médula Ósea (UTMO), del Hospital Dr. Luis Calvo Mackenna, desde abril de 2016 hasta mayo de 2019. Se incluyeron niños con cáncer y antecedente de TPH que consultaron por fiebre en forma ambulatoria (urgencias o policlínico de UTMO) o que cursaron con fiebre durante su hospitalización post trasplante, previa firma de consentimiento por los padres o tutores legales y asentimiento informado en los niños mayores de ocho años. Se excluyó a los pacientes sometidos a TPH por causa no oncológica y aquellos a quienes al momento de la evaluación clínica no presentaban fiebre. Este estudio fue aprobado por el Comité de Ética en Investigación en Seres Humanos de la Facultad de Medicina, Universidad de Chile.

Una vez enrolados en el estudio, los pacientes se sometieron a una evaluación clínica, de laboratorio, de estudio de imágenes, estudio bacteriológico y estudio viral respiratorio. Los pacientes recibieron terapia antiinfecciosa de acuerdo a la sospecha clínica, resultados de laboratorio y evolución por parte del equipo médico tratante de la UTMO del hospital.

Después del alta, un investigador ciego y externo clasificó la etiología principal en cada episodio enrolado en las siguientes categorías: etiología no precisada; infección bacteriana; infección respiratoria viral. Los criterios que determinaron la clasificación para cada tipo de episodio son la sumatoria de la evaluación clínica con sus signos y síntomas, estudios de laboratorio complementarios y detección de algún agente etiológico, como en todo proceso diagnóstico, detallados a continuación: 


\section{Estudio de variables de evolución clínica al egreso}

Se evaluaron las siguientes variables clínicas: infección respiratoria aguda (IRA) alta y baja;ingreso a unidad de cuidados intensivos (UCI); necesidad de ventilación mecánica; mortalidad y suspensión de antimicrobianos.

\section{Definiciones}

Fiebre: Temperatura axilar única $\geq 38^{\circ} \mathrm{C}$.

IRV: Detección de al menos un virus respiratorio en una muestra nasofaríngea por RPC.

IRA alta/baja: infección del tracto respiratorio que afecta clínicamente desde la laringe hacia proximal o hacia distal de la laringe, más detección de virus respiratorio, respectivamente.

IB: se consideró la detección de bacteriemia o el aislamiento de bacterias de un sitio normalmente estéril o signos clínicos altamente sugerentes de una infección bacteriana localizada, con afectación parenquimatosa, con o sin aislamiento microbiológico.

Etiología no precisada (ENP): episodio febril en el cual no se logró determinar agente microbiológico y que no cumple con los criterios clínicos de infección bacteriana ni viral mencionados previamente.

\section{Tamaño muestral y análisis estadístico}

Se realizó un muestreo no probabilístico por conveniencia, enrolando todos los casos presentados dentro del período de tiempo del estudio. Las variables categóricas se compararon con la prueba de $\chi^{2}$ en función del número de grupos de comparación. Las variables continuas se compararon entre los tres grupos (infección respiratoria viral, infección bacteriana e infección de etiología no precisada) de acuerdo con su distribución paramétrica o no paramétrica mediante la prueba Kruskal Wallis y ANOVA, según correspondiera. Para el análisis estadístico se utilizó el programa computacional STATA v11 y se consideró significativo un valor de $\mathrm{p}<0,05$.

\section{Resultados}

\section{Variables demográficas y antecedentes clínicos}

Se estudiaron 56 episodios febriles en 41 niños. Del total de episodios, en 35 de ellos (63\%) se detectó una IRV, en $12(21 \%)$ una IB y en $9(16 \%)$ no se logró precisar su naturaleza. La mediana de edad fue 8,5 años (RIQ 1-17 años), siendo $62 \%$ hombres. El tipo de cáncer más frecuente fue la leucemia linfoblástica aguda en recaída en 18 episodios (32\%), seguido de leucemia mieloide aguda en 15 (27\%). 
En relación con el tipo de TPH, hubo predominio de trasplante alogénico, observado en 50 episodios febriles $(89 \%)$, siendo el trasplante de sangre de cordón no emparentado el más frecuente con 38 casos (68\%). La mediana de días post trasplante al iniciarse el episodio febril fue de 90,5 días (RIQ 3-1.713 días). El 100\% de los acondicionamientos pre-trasplante fueron mieloablativos y en 27 episodios (48\%) existía antecedente de EICH. Con respecto al uso de inmunosupresión dentro de las dos semanas previas a la hospitalización, se pesquisó uso de corticosteroides en 41 episodios (73\%). Además, en $39(70 \%)$ se utilizó algún tipo de inmunosupresión no esteroidal. En la Tabla 1 se describen las principales características demográficas y clínicas de los grupos según etiología de la infección, no observándose diferencias significativas entre los grupos.

En relación con los días post trasplante al momento del inicio del episodio febril, se observó una tendencia de las IRV a presentarse más tardíamente, con una mediana de 105 días, a diferencia de los grupos con IB y de ENP, que se presentaron con más frecuencia dentro de los primeros 100 días post trasplante, con una mediana de 11 y 75 días, respectivamente (p: 0,087).

\section{Caracterización clínica y de laboratorio al ingreso de acuerdo con la etiología}

$\mathrm{Al}$ comparar los síntomas y signos al ingreso en los grupos, según precisión etiológica del episodio febril, se detectó que en el grupo de IRV, 89\% fue sintomático respiratorio al ingreso, mientras que en los grupos de IB y de ENP se observó una tendencia menor, con 58\% y $67 \%$, respectivamente (p: 0,05 ). Dos pacientes del grupo IRV se mantuvieron asintomáticos durante toda la hospitalización. También la presencia de tos (p: 0,018) y rinorrea $(\mathrm{p}: 0,025)$ fue más frecuente en el grupo de IRV, al comparar con los otros dos grupos. Dentro de los exámenes de laboratorio al ingreso, si bien no hubo diferencias significativas respecto con la PCR del día 1, hubo una tendencia a presentar un valor más elevado en IB al día 2 (p: 0,062) y fue significativamente mayor al día 3 de evolución (p: 0,024). En la Tabla 2 se detallan los principales hallazgos clínicos y de laboratorio al ingreso.

\section{Episodios febriles con detección de virus respiratorio}

De los 56 episodios febriles, en 46 de ellos se detectó uno o más virus respiratorios mediante RPC múltiple,

Tabla 1. Principales variables demográficas y antecedentes clínicos por etiología en episodio de fiebre en pacientes pediátricos receptores de trasplante de precursores hematopoyéticos

\begin{tabular}{|c|c|c|c|}
\hline Variable & $\begin{array}{l}\text { Etiología no precisada } \\
\qquad(n=9)\end{array}$ & $\begin{array}{l}\text { Infección bacteriana } \\
\qquad(\mathrm{n}=12)\end{array}$ & $\begin{array}{l}\text { Infección respi } \\
\text { viral }(n=3\end{array}$ \\
\hline \multicolumn{4}{|l|}{ Antecedentes demográficos $\approx$} \\
\hline Edad en años $\approx$ & $5(1-15)$ & $9(1-17)$ & $9(1-16)$ \\
\hline Sexo masculino $\approx$ & $6(67)$ & $6(50)$ & $23(66)$ \\
\hline \multicolumn{4}{|l|}{ Tipo de cáncer $\approx$} \\
\hline Leucemia linfoblástica aguda & $3(33)$ & $1(8)$ & $8(23)$ \\
\hline Leucemia linfoblástica aguda, recaída & $1(11)$ & $3(25)$ & $14(40)$ \\
\hline Leucemia mieloide aguda & $1(11)$ & $5(42)$ & $9(26)$ \\
\hline Leucemia mieloide aguda, recaída & 0 & $1(8)$ & $1(3)$ \\
\hline Tumores sólidos* & $3(33)$ & 0 & $2(6)$ \\
\hline Otros** & $1(11)$ & $2(17)$ & $1(3)$ \\
\hline
\end{tabular}

Antecedentes del trasplante $\approx$

Tipo de trasplante $\approx$

TPH Autólogo

Trasplante de sangre de cordón no emparentado

TPH Donante familiar idéntico

TPH haploidéntico

Días post $\mathrm{TPH} \cong$

Antecedente de $\mathrm{EICH} \approx$

$2(17)$

p

$3(33)$
$5(56)$
$1(11)$
0
$75(7-232)$
$3(33)$
$6(67)$
$6(67)$

$1(8)$
$7(58)$
$4(33)$
0
$2(5-350)$
$4(33)$
$11(92)$
$9(75)$

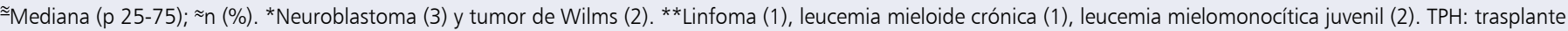
de precursores hematopoyéticos; EICH: enfermedad de injerto contra hospedero. 


\begin{tabular}{|c|c|c|c|c|}
\hline Variable & $\begin{array}{l}\text { Etiología no precisada } \\
\qquad(n=9)\end{array}$ & $\begin{array}{l}\text { Infección bacteriana } \\
\qquad(n=12)\end{array}$ & $\begin{array}{c}\text { Infección respiratoria } \\
\text { viral }(n=35)\end{array}$ & $\mathbf{p}$ \\
\hline \multicolumn{5}{|l|}{ Signos y/o síntomas respiratorios $\approx$} \\
\hline Tos & $5(56)$ & $3(25)$ & $25(71)$ & 0,018 \\
\hline Rinorrea & $3(33)$ & $3(25)$ & $23(66)$ & 0,025 \\
\hline Auscultación pulmonar alterada & $2(22)$ & $3(25)$ & $20(57)$ & 0,052 \\
\hline Episodios con algún* signo y/o síntoma respiratorio & $6(67)$ & $7(58)$ & $31(89)$ & 0,056 \\
\hline Recuento absoluto de neutrófilos $\left(\mathrm{mm}^{3}\right) \approx$ & $3.827(1.200-7.513)$ & $1.805(0-7.437)$ & $2.334(0-8.684)$ & 0,398 \\
\hline Recuento absoluto de neutrófilos $<500$ mm & 0 & $3(25)$ & $3(9)$ & \\
\hline Recuento absoluto de linfocitos $\left(\mathrm{mm}^{3}\right) \approx \widetilde{\simeq}$ & $681(249-6.783)$ & $410(0-2.313)$ & $827(0-7.054)$ & 0,477 \\
\hline Recuento absoluto de linfocitos $<200 \mathrm{~mm}^{3} \approx$ & 0 & $4(33)$ & $7(20)$ & \\
\hline Hemocultivos positivos $\approx$ & 0 & $6(50)$ & 0 & \\
\hline Proteína $C$ reactiva $(\mathrm{mg} / \mathrm{l}) \approx$ & $11(5-75)$ & $41(5-163)$ & $25(5-205)$ & 0,176 \\
\hline
\end{tabular}

siendo rinovirus el virus más frecuente (54\%), seguido de coronavirus (15\%) y virus parainfluenza (11\%) (Tabla 3 ). Además, se realizó medición de carga viral en un subgrupo de 24 episodios. La mediana de copias detectadas para los virus analizados (rinovirus, coronavirus, parainfluenza y virus respiratorio sincicial) se detalla en la Tabla 3, destacando rinovirus en una mayor cantidad de episodios (n: 14) y la cuantificación viral, con una mediana de 29.450 copias/ml (RIQ 250-3.152.375 copias/ml). El episodio con mayor carga viral se detectó en un episodio de rinovirus, con 3.152 .375 copias $/ \mathrm{ml}$, y se trató de un paciente cursando neutropenia febril a los 15 días post trasplante, con clínica de IRA baja, sin requerimiento de oxigenoterapia, ventilación mecánica ni UCI. Por otra parte, se detectó un paciente asintomático respiratorio con una carga de rinovirus de 154.525 copias $/ \mathrm{ml}$. Si se revisa el total de episodios que requirieron oxigenoterapia en el grupo de IRV, en aquellos que se midió carga viral son cuatro afectados: dos episodios con coronavirus con $40.800 \mathrm{y}$ 57.000 copias $/ \mathrm{ml}$, respectivamente, uno de rinovirus con una carga viral $<250$ copias $/ \mathrm{ml}$ y uno con una carga detectada de 1.900 copias $/ \mathrm{ml}$ de virus respiratorio sincicial. Este último paciente fue uno de los dos que requirió UCI, pero su ingreso fue debido a un shock hipovolémico por un síndrome diarreico agudo por rotavirus. Se analizó la relación entre el agente respiratorio detectado y la presencia de IRA baja, no detectándose una asociación significativa, pese a haber un mayor predominio de esta patología en los pacientes con coronavirus ( $86 \%$ de los niños con detección de coronavirus tuvo IRA baja).
Tabla 3. Virus respiratorios detectados y su carga viral, en episodios de fiebre en pacientes pediátricos receptores de trasplante de precursores hematopoyéticos

\begin{tabular}{lccc}
\hline Tipo de virus & $\begin{array}{c}\text { Virus } \\
\text { respiratorios } \\
\text { detectados } \approx \\
(\mathbf{n}=\mathbf{4 6})\end{array}$ & $\begin{array}{c}\text { Muestras con } \\
\text { medición de } \\
\text { carga viral } \\
(\mathbf{n}=\mathbf{2 1})\end{array}$ & $\begin{array}{c}\text { Carga viral } \approx \\
\text { (copias/ml) }\end{array}$ \\
\hline Rinovirus & $25(54)$ & $14(67)$ & $29.450(250-3.152 .375)$ \\
Coronavirus & $7(15)$ & $5(24)$ & $40.800(5.950-82.675)$ \\
Parainfluenza & $5(11)$ & & \\
Virus respiratorio sincicial & $4(9)$ & $2(9)$ & $428.450(1.900-855.000)$ \\
Adenovirus & $3(7)$ & & \\
Influenza & $2(4)$ & & \\
\hline$\approx$ Mediana $(\mathrm{p} \mathrm{25-75);} \approx \mathrm{n}(\%)$. & & & \\
\hline
\end{tabular}

Con respecto a la presencia de co-infecciones, del total de episodios febriles se observó la presencia de más de un virus respiratorio en 14 episodios (40\%) del grupo con IRV, y en el grupo con IB hubo co-infección con virus respiratorio en cinco episodios $(42 \%)$.

\section{Episodios febriles con detección de infección bacteriana}

De los casos con IB detectada, los principales agentes aislados en hemocultivos fueron Streptococcus grupo viridans en seis episodios y Staphylococcus coagulasa negativa en un episodio, pero este último se aisló sólo 
Figura 1. Heatmap de niveles de citoquinas en lavado nasal en episodios de fiebre en pacientes pediátricos receptores de trasplante de precursores hematopoyéticos según etiología.

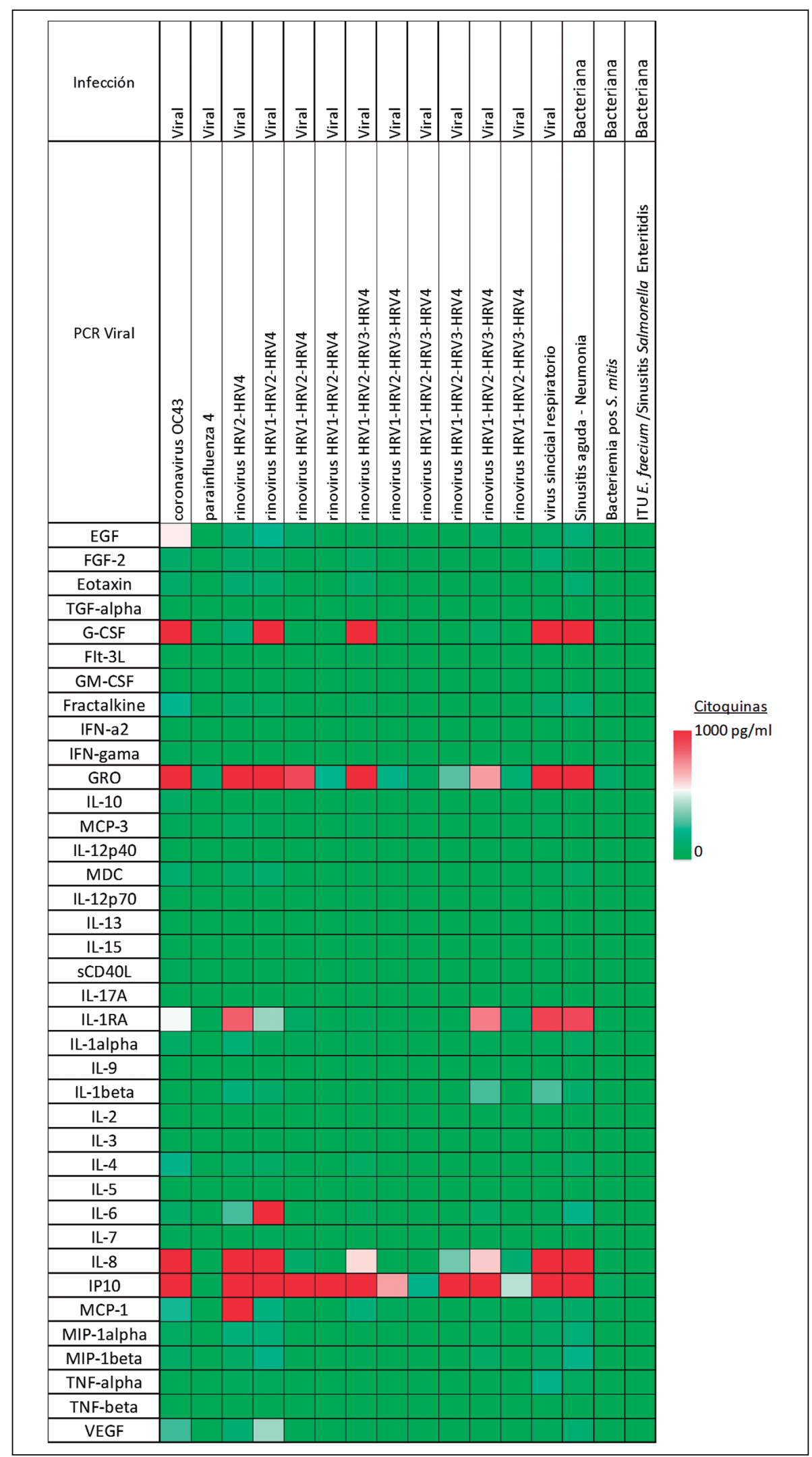


en una muestra de CVC, no constituyendo agente causal de bacteriemia en ese paciente. Se pesquisaron tres infecciones del tracto urinario, dos casos causados por Escherichia coli y uno por Enterococcus faecium. Otras infecciones fueron: una sinusitis por Salmonella Enteritidis, confirmada con cultivo de tejido de seno maxilar e imagen compatible con compromiso sinusal; una neumonía por Klebsiella pneumoniae con clínica, compromiso radiológico y presencia del microorganismo descrito en cultivo de secreción traqueal y una infección de piel y tejidos blandos sin agente aislado, pero evidenciando un aumento de volumen alrededor del CVC de larga duración (Port-a-Cath ${ }^{\circledR}$ ) con cambios ecográficos consistentes en una colección hipoecogénica y cambios inflamatorios de la grasa circundante, presentando elevación de PCR y buena respuesta tras el retiro del dispositivo y tratamiento antimicrobiano.

\section{Episodios febriles sin etiología precisada}

De los nueve episodios de ENP, uno de ellos consistió en un paciente con más de 100 días post trasplante con diagnóstico de IRA baja, que evolucionó con shock y SDRA grave, siendo tratado en forma empírica con cobertura antiviral, antibacteriana y antifúngica, requiriendo, además, manejo en UCI con VM. Los demás casos no presentaron criterios de gravedad, dos fueron catalogados como IRA alta, otros dos episodios tuvieron hallazgos clínicos de mucositis oral y diarrea, respectivamente, y cuatro episodios cursaron sin foco clínico identificado.

\section{Perfil de citoquinas en muestras de lavado nasal}

Se analizaron las concentraciones de citoquinas en un subgrupo de 16 episodios febriles con detección viral. De ellos, 13 fueron clasificados dentro del grupo de IRV y los 3 restantes, con co-infección bacteriana, se clasificaron como IB. No se observaron diferencias significativas en las concentraciones de citoquinas a nivel nasal entre los casos de IRV e IB. En la Figura 1 se ilustran estos hallazgos mediante un heatmap, que agrupa los episodios febriles según la microbiología y niveles de citoquinas pesquisados.

\section{Hallazgos clínicos en los episodios febriles}

Del total de episodios de fiebre estudiados, se diagnosticó IRA en 40 de ellos (71\%). En la Tabla 4 se muestran los resultados clínicos según etiología de la infección. En 94\% de los pacientes con IRV hubo una IRA sintomática, versus 33\% en el grupo de infecciones bacterianas y $33 \%$ en los ENP ( $p<0,001)$; significativa fue también la presencia de IRA baja, correspondiendo a $69 \%$ del total de las IRV $(\mathrm{p}<0,001)$. En este análisis no se detectaron diferencias significativas con respecto al uso de oxigenoterapia, ventilación mecánica, ingreso a UCI,

\begin{tabular}{|c|c|c|c|c|}
\hline Variable & $\begin{array}{l}\text { Etiología no precisada } \\
\qquad(\mathrm{n}=9)\end{array}$ & $\begin{array}{l}\text { Infección bacteriana } \\
\qquad(n=12)\end{array}$ & $\begin{array}{l}\text { Infección respiratoria } \\
\quad \text { viral }(n=35)\end{array}$ & p \\
\hline \multicolumn{5}{|l|}{ Infección respiratoria aguda } \\
\hline Total & $3(33)$ & $4(33)$ & $33(94)$ & $<0,001$ \\
\hline IRA alta & $2(22)$ & $2(17)$ & $9(26)$ & \\
\hline IRA baja & $1(11)$ & $2(17)$ & $24(69)$ & \\
\hline Oxigenoterapia & $1(11)$ & $5(42)$ & $14(40)$ & 0,227 \\
\hline Ingreso a UCl & $1(11)$ & $2(17)$ & $4(11)$ & 0,886 \\
\hline Uso de ventilación mecánica & $1(11)$ & 0 & $1(3)$ & 0,371 \\
\hline Días de fiebre tras el ingreso $\cong$ & $3(1-30)$ & $3,5(1-11)$ & $2(0-12)$ & 0,119 \\
\hline Días de hospitalización $\mathrm{n}$ & $9(6-30)$ & $14(4-29)$ & $12(0-33)$ & 0,582 \\
\hline Mortalidad & 0 & 0 & 0 & \\
\hline Suspensión de antimicrobianos & 0 & 0 & $9(26)$ & 0,040 \\
\hline
\end{tabular}


días de fiebre tras el ingreso, ni con relación a los días de hospitalización. No se observó mortalidad alguna en los episodios febriles. Tras la detección viral mediante RPC, el equipo médico tratante de la UTMO decidió suspender el tratamiento antimicrobiano en $26 \%$ de los pacientes con IRV (p: 0,04), lo anterior asociado a la apreciación clínica e interpretación de exámenes de laboratorio por cada facultativo.

\section{Discusión}

Las IRV son frecuentes en pediatría, tanto en pacientes inmunocompetentes como en inmunosuprimidos. Este estudio, realizado en pacientes receptores de TPH, confirma a los agentes respiratorios virales como causa frecuente de infección, detectándose al menos un virus mediante técnicas de biología molecular en más de $80 \%$ de los episodios febriles analizados (46/56). La presencia de los distintos tipos de virus fue concordante con la circulación estacional habitual y rinovirus prevaleció durante todo el año sin diferencias significativas. Tanto en nuestro estudio como en otras publicaciones sobre virus respiratorios en $\mathrm{TPH}^{4,5,31}$, el virus respiratorio detectado con mayor frecuencia fue rinovirus. La detección de IRV en niños receptores de TPH se asoció a diagnóstico de IRA, con sintomatología respiratoria al ingreso en más de $90 \%$ de los casos (con tos y rinorrea como síntomas frecuentes) y $69 \%$ de ellos con diagnóstico de IRA baja. Por el contrario, los pacientes con IB y ENP presentaron sintomatología de infección respiratoria en sólo $30 \%$ de los casos.

Una acuciosa anamnesis y un examen físico detallado pueden orientar la etiología del proceso febril en pacientes post TPH y continúan siendo pilares fundamentales en la evaluación clínica, especialmente si se considera que las técnicas de biología molecular sólo detectan el material genético del microorganismo.

En cuanto a exámenes de laboratorio, es destacable la elevación de PCR desde el día 2 de evolución, surgiendo como un examen orientador, en especial, su elevación desde el día 3 de fiebre en los episodios de IB. Fisher y cols., describieron la presencia de neutropenia y linfopenia como hallazgos frecuentes durante la semana anterior a la hospitalización por IRV (41\% y 53\%, respectivamente) $)^{4}$. Nuestro estudio analizó la presencia de neutropenia y linfopenia al ingreso en los episodios febriles con IRV, detectándose valores más bajos a los descritos $(9 \%$ y $20 \%$, respectivamente). Este hallazgo podría explicarse, en parte, por el tiempo transcurrido desde el trasplante, el que fue mayor a 100 días en los pacientes con IRV, mientras que en los pacientes con etiología no precisada y bacteriana fue menor, con 75 y 11 días, respectivamente.

Dado que no se cuenta con pautas específicas o escalas de aproximación diagnóstica estandarizadas para este grupo especial de pacientes, se podría plantear el diseño, a futuro, de pautas de valorización que incluya, entre otros, los parámetros clínicos y de laboratorio descritos previamente. Una revisión reciente ${ }^{16}$ menciona como factor predisponente para IRV en pacientes que han recibido un TPH la inmunosupresión prolongada, tanto humoral como mediada por células T. Por otro lado, Fisher y cols. ${ }^{4}$, describieron que $36 \%$ de los pacientes pediátricos que han recibido un TPH y presentaron al menos un episodio de hospitalización por IRV, había recibido dos o más agentes inmunosupresores para el tratamiento de la EICH en la semana anterior al inicio del episodio febril que motivó dicha hospitalización ${ }^{4}$. En dicho estudio, los pacientes que recibieron corticosteroides en los siete días previos al inicio de la IRV presentaban tres veces más probabilidades de experimentar complicaciones pulmonares. Por el contrario, la exposición reciente a terapias inmunosupresoras no esteroidales no se asoció con peores resultados ${ }^{4}$. En nuestro estudio, a pesar del uso de corticosteroides en $73 \%$ de los pacientes y de inmunosupresión no esteroidal en 70\% dentro de las dos semanas previas a la hospitalización, estas terapias no se asociaron significativamente a una mayor frecuencia de IRV o IB ni a peor desenlace clínico. El análisis de un mayor número de pacientes se hace necesario para confirmar estos resultados en nuestra población.

Acerca del tipo de trasplante, un estudio retrospectivo pediátrico demostró una mortalidad mayor en receptores alogénicos en comparación con receptores autólogos $(13,3 \% \text { frente a } 4,8 \%)^{6}$. En Chile, el TPH más frecuente es el alogénico ${ }^{17,18}$, lo que se vio reflejado en nuestro estudio; sin embargo, no observamos casos fatales. Tampoco observamos una asociación estadística entre algún tipo particular de TPH y etiología de la infección.

Con respecto a la carga viral detectada en los episodios de IRV y su resultado clínico, no se observó correlación alguna significativa entre gravedad clínica y el número de copias/ml. Cabe destacar que la carga viral como factor de riesgo de enfermedad grave por IRA continúa siendo controversial en pacientes inmunocompetentes. En población adulta receptora de TPH se ha descrito la asociación de altas cargas virales con excreción viral prolongada en casos de coronavirus ${ }^{19}$ y rinovirus ${ }^{20}$. Es probable que en nuestros pacientes las cargas virales sean parte de una compleja interacción agente-hospedero, donde interactúen tanto la respuesta inmune como la replicación viral. Siguiendo esa línea, nuestro análisis de citoquinas nasales, si bien no evidenció resultados con significancia estadística al comparar los grupos con IRV e IB, mostró en forma general una disminución en las concentraciones de la mayoría de las citoquinas medidas, lo que podría ser explicable por una disminución de la capacidad de respuesta inmune en las mucosas en ambos grupos post 
y seis niños, relacionó el uso de antimicrobianos dentro de las tres semanas previo al TPH con la incidencia de IRV causada por metapneumovirus, virus parainfluenza y virus respiratorio sincicial dentro de los 100 primeros días post TPH y su evolución; concluyó que la exposición acumulada a antimicrobianos inmediatamente antes del inicio de IRV es un factor de riesgo para la progresión de la enfermedad por los virus mencionados, después del trasplante. Si bien no se pudo determinar el impacto real relacionado a familia de antimicrobianos, hubo una tendencia entre el uso de antimicrobianos con actividad anaeróbica significativa o de carbapenémicos y un mayor riesgo de progresión ${ }^{30}$. Lo anterior sugiere la necesidad de profundizar sobre esta área de estudio, relacionando la progresión de la IRV y la microbiota respiratoria bacteriana de los pacientes que han recibido un TPH.

Un hecho a destacar en este estudio es que, tras la detección del virus respiratorio por RPC, el equipo médico tratante decidió suspender el tratamiento antimicrobiano en $26 \%$ de los pacientes con IRV. Este hallazgo apoya el concepto de que un proceso diagnóstico clínico detallado, estudio de laboratorio, más el apoyo de técnicas moleculares en estos pacientes puede, eventualmente, optimizar el uso racional de antimicrobianos. Por lo anterior, podría ser de importancia contar con este tipo de técnicas diagnósticas en centros donde se realice el manejo de pacientes inmunocomprometidos $y$, sobre todo, en centros de trasplante. Nuestro reporte de los virus respiratorios pesquisados en niños sometidos a TPH fue concordante con lo señalado en la literatura médica ${ }^{4,5}$.

Dentro de las limitaciones de este estudio, destaca que no fue posible contar con un grupo control de pacientes sanos y tampoco hubo intervención terapéutica por parte de los investigadores. Una estandarización del manejo, basándose en variables clínicas establecidas y en resultados positivos de técnicas de biología molecular para virus respiratorios, podría haber apoyado la suspensión de antimicrobianos en un número mayor al observado. Tampoco se realizó medición de carga viral y de las concentraciones de citoquinas en muestra de lavado nasal a todos los episodios, resultando esto en una información preliminar interesante, pero que requiere de un mayor número de episodios para obtener conclusiones más definitivas.

En suma, en este estudio la causa más frecuente de episodios febriles en pacientes receptores de TPH fue la IRA y dentro de ellas, la principal etiología correspondió a virus respiratorios. La IRV se presentó con síntomas respiratorios al ingreso, destacando la presencia de tos y coriza. Una evaluación clínica detallada en conjunto con exámenes de laboratorio y el uso precoz de técnicas de diagnóstico molecular podrían contribuir a un eventual uso más racional de antimicrobianos en este grupo especial de pacientes. 


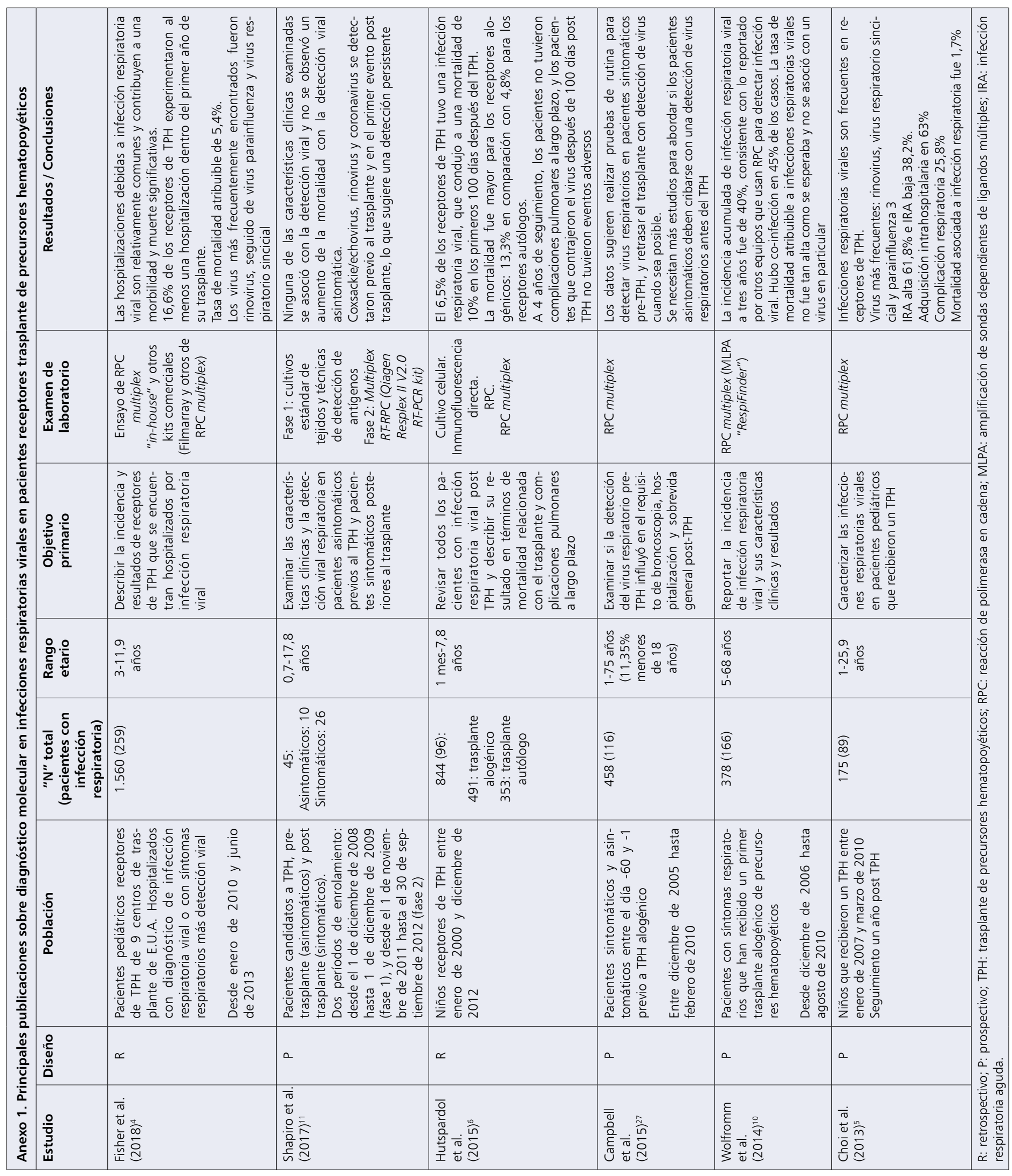




\section{Referencias bibliográficas}

1.- Colvin J, Muenzer J, Jaffe D, Smason A, Deych E, Shannon W, et al. Detection of viruses in young children with fever without an apparent source. Pediatrics. 2012; 130 (6): 1455-62. doi: 10.1542/peds.2012-1391. Epub 2012 Nov 5.

2.- Renaud C, Angela P. Changing epidemiology of respiratory viral infections in hematopoietic cell transplant recipients and solid organ transplant recipients. Curr Opin Infect Dis. 2011; 24: 33343. doi: 10.1097/QCO.0b013e3283480440.

3.- Chemaly R, Shah D, Boeckh M. Management of respiratory viral infections in hematopoietic cell transplant recipients and patients with hematologic malignancies. Clin Infect Dis. 2014; 59 (Suppl 5): 344-51. doi: 10.1093/cid/ ciu623.

4.- Fisher B, Danziger-Isakov L, Sweet L, Munoz F, Maron G, Tuomanen E, et al. A Multicenter consortium to define the epidemiology and outcomes of inpatient respiratory viral infections in pediatric hematopoietic stem cell transplant recipients. J Pediatric Infect Dis Soc. 2018; 7 (4): 275-82. doi: 10.1093/jpids/pix051.

5.- Choi J H, Choi E H, Kang H J, Park K D, Park S S, Shin H Y, et al. Respiratory viral infections after hematopoietic stem cell transplantation in children. J Korean Med Sci 2013; 28 (1): 3641. doi: 10.3346/jkms.2013.28.1.36.

6.- Hutspardol S, Essa M, Richardson S, Schechter T, Ali M, Krueger J, et al. Significant transplantation-related mortality from respiratory virus infections within the first one hundred days in children after hematopoietic stem cell transplantation. Biol Blood Marrow Transplant 2015; 21 (10): 1802-7. doi: 10.1016/j.bbmt.2015.06.015. Epub 2015 Jun 25.

7.- Loeffelholz $\mathrm{M}$ and Chonmaitree T. Advances in diagnosis of respiratory virus infections. Int J Microbiol 2010; 2010 (126049): 1-5. doi: org/10.1155/2010/126049.

8.- Caliendo A. Multiplex PCR and emerging technologies for the detection of respiratory pathogens. Clin Infect Dis 2011; 52 (Suppl 4): 326-30. doi: 10.1093/cid/cir047.

9.- Poritz M A, Blaschke A J, Byington C L, Meyers L, Nilsson K, et al. FilmArray, an automated nested multiplex PCR system for multi-pathogen detection : development and application to respiratory tract infection. PLoS One 2011; 6 (10): e26047. doi: 10.1371/journal. pone. 0026047.

10.- Wolfromm A, Porcher R, Legoff J, Peffault de Latour R, Xhaard A, Sicre de Fontbrune F, et al. Viral respiratory infections diagnosed by multiplex pcr after allogeneic hematopoietic stem cell transplantation: long-term incidence and outcome. Biol Blood Marrow Transpl 2014; 20 (8): 1238-41. doi: 10.1016/j.bbmt.2014.04.004. Epub 2014 Apr 13.

11.- Shapiro D, López-Marti M, Woods C W, Nicholson B P, Martin P L, Park L P, et al. Respiratory viral detection in the pediatric hematopoietic stem cell transplant population. Pediatr Infect Dis 2017; 2 (3): 46. doi: 10.21767/2573-0282.100046.

12.- Imanishi J. Expression of cytokines in bacterial and viral infections and their biochemical aspects. J Biochem 2000; 127 (4): 525-30. doi: 10.1093/oxfordjournals.jbchem.a022636.

13.- Lacy P. Editorial: Secretion of cytokines and chemokines by innate immune cells. Front Immunol. 2015; 6 (April): 6-7. doi: 10.3389/ fimmu.2015.00190.

14.- Khaitov M R, Edwards M R, Walton R P, Rohde G, Contoli M, Papi A, et al. Respiratory virus induction of alpha- beta- and lambdainterferons in bronchial epithelial cells and peripheral blood mononuclear cells. Allergy. 2009; 64 (3): 375-86. doi: 10.1111/j.13989995.2008.01826.x. Epub 2009 Jan 28.

15.- Liu K T, Liu Y H, Lin Ch Y, Kuo P L, Yen M C. Inflammatory molecules expression pattern for identifying pathogen species in febrile patient serum. Exp Ther Med. 2016; 12: 312-8. doi: 10.3892/etm.2016.3323.

16.- Pochon $\mathrm{C}$ and Voigt $\mathrm{S}$. Respiratory virus infections in hematopoietic cell transplant recipients. Front Microbiol 2019; 9 (3294): 1-17. doi: 10.3389/fmicb.2018.03294.

17.- Palma J, Mosso C, Paris C, Campbell M, Tong $\mathrm{X}$, King A, et al. Establishment of a pediatric HSCT program in a public hospital in Chile. Pediatr Blood Cancer. 2006; 46: 803-10. doi: $10.1002 /$ pbc. 20678 .

18.- Guías Clínicas Sociedad Chilena de Trasplante, 2010; Capitulo XIV: Trasplante de Progenitores Hematopoyéticos en Pediatría: p561-623. https:/www.sociedaddetrasplante.cl/biblioteca/ gui-as-cli-nicas-sociedad-chilena-de-trasplante/ category/25-capitulo-xiv-trasplante-deprogenitores-hematopoyeticos-en-pediatria. html

19.- Ogimi C, Greninger A L, Waghmare A, Kuypers J M, Shean R C, Xie H, et al. Prolonged shedding of human coronavirus in hematopoietic cell transplant recipients: risk factors and viral genome evolution. J Infect Dis 2017; 216 (2): 203-9. doi: 10.1093/infdis/ jix264.

20.- Ogimi C, Xie H, Leisenring W M, Kuypers J M, Jerome K R, Campbell A, et al. Initial high viral load is associated with prolonged shedding of human rhinovirus in allogeneic hematopoietic cell transplant recipients. Biol Blood Marrow Transplant 2018; 24 (10): 2160 3. doi: 10.1016/j.bbmt.2018.07.006.

21.- Vela M, Rosal T, Pérez-Martínez A, Valentín J, Casas I, Pozo F, et al. Possible role of highly activated mucosal NK cells against viral respiratory infections in children undergoing haematopoietic stem cell transplantation. Sci Rep 2019; 9 (1): 18792. doi: 10.1038/s41598019-55398-y.

22.- Murphy P M. The molecular biology of leukocyte receptors. Annu Rev Immunol. 1994; 12 (1): 593-633. doi: 10.1146/annurev. iy.12.040194.003113.

23.- Alves M, Schögler A, Muster R, Kronig MN, Kieninger E, Kopf BS, et al. IP-10 is selectively produced in the airways upon respiratory virus infection. Comunicación presentada en el European Respiratory Society Annual Congress, 2013. https://erj.ersjournals.com/ content/42/Suppl_57/P3877.

24.- Camp J V and Jonsson C B. A role for neutrophils in viral respiratory disease. Front Immunol. 2017; 8: 550. doi: 10.3389/ fimmu.2017.00550.

25.- Kim Y J, Waghmare A, Kuypers J M, Jerome K R, Pergam S, Xie H, et al. Impact of pretransplant respiratory virus detection through universal screening in children undergoing hematopoietic cell transplantation (HCT). Biol Blood Marrow Transplant. 2017; 23 (3): S190-1. doi: 10.1016/j. bbmt.2016.12.370.

26.- Versluys B, Bierings M, Murk L, Wolfs T, Lindemans $\mathrm{C}$, et al. Infection with a respiratory virus before hematopoietic cell transplantation is associated with alloimmune-mediated lung syndromes. J Allergy Clin Immunol 2018; 141 (2): 697-703.e8. doi: 10.1016/j. jaci.2017.03.055. Epub 2017 Jul 15.

27.- Campbell A P, Guthrie K A, Englund J A, Farney R M, Minerich E L, Kuypers J, et al. Clinical outcomes associated with respiratory virus detection before allogeneic hematopoietic stem cell transplantation. Clin Infect Dis 2015; 61 (2): 192-202. doi: 10.1093/cid/civ272.

28.- Ottaviano G, Lucchini G, Breuer J, Furtado-Silva J M, Lazareva A, Ciocarlie $\mathrm{O}$, et al. Delaying haematopoietic stem cell transplantation in children with viral respiratory infections reduces transplant-related mortality. Br J Haematol 2020; 188 (4): 560-9. doi: 10.1111/bjh.16216. Epub 2019 Sep 30.

29.- Mowrer C, Lee B, Goyal R, Selvarangan R, Schuster J. Outcome of children with rhinovirus detection prior to allogeneic hematopoietic cell 
transplant. Pediatr Transplant 2018; 22 (8): e13301. doi: 10.1111/petr.13301. Epub 2018 Oct 19.

30.- Ogimi C, Krantz E, Golob J, Waghmare A, Liu $\mathrm{C}$, Leisenring W, et al. Antibiotic exposure prior to respiratory viral infection is associated with progression to lower respiratory tract disease in allogeneic hematopoietic cell transplant recipients. Biol Blood Marrow Transplant 2018; 24 (11): 2293-2301. doi: 10.1016/j.bbmt.2018.05.016.

31.- Marinelli T, Wee L Y A, Rowe E, Chhetri
R, Friel O, Higgins G, et al. Respiratory viruses cause late morbidity in recipients of hematopoietic stem cell transplantation. Biol Blood Marrow Transplant 2020; 26 (4): 782-8. doi: 10.1016/j.bbmt.2019.12.724. Epub 2019 Dec 20. 